\title{
ONLINE ÉLELMISZERVÁSÁRLÁSI SZOKÁSOK ÉS LEHETÓSÉGEK VIZSGÁLATA MAGYAR ÉS AMERIKAI ONLINE VÁSÁRLÓK KÖRÉBEN
}

\author{
36 \\ INVESTIGATION INTO ONLINE CUSTOMER BEHAVIOUR AND OPPORTUNITIES OF THE \\ FOOD SHOPPING AMONG HUNGARIAN AND AMERICAN ONLINE CONSUMERS
}

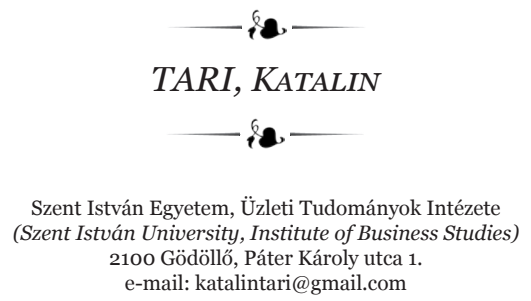

si Nowadays, it is so much easier to interact with each other (two-way communication) from all over the world as never before. This possibility has only been available for a few people - for the military at first - but after some decades, it became accessible to everyone. Online customer demand increased a lot, for example by the big boom of Web 2.o. by Mark Zuckerberg's Facebook and by the introduction of Steve Jobs' iPad. This topic is of interest, because companies from all over the world would like to find the most effective and cheapest methods to reach and keep their online consumers (worldwide). Therefore, they need to discover more about their consumers' behaviour without generating high expenditure. This article focuses on the behavioural analysis of the online consumer (non-representative) population between Hungary and the USA. The background for my research consists of the awareness of the contents of e-markets. The analysed questionnaire was given out online $(\mathrm{N}=932)$ and people with high incomes (outliers) were excluded. Before the analysis of the database, I presumed that the consumers have a focus on online selling products and/or services. In this research we will examine the differences and identities of the behaviour of Hungarian and American customers based on online purchases. I have used Factorial ANOVA to analyse my database and found answers to my research questions about the most popular online goods and/or services. Furthermore, the differences and similarities of the behaviour between American and Hungarian consumers have been examined.

KuLCSSZAVAK: e-marketing, fogyasztói magatartás, országok közti különbségek

JEL-KóDok (JEL CODES): E7O

DOI: https://doi.org/10.20494/TM/5/2/3

\section{BEVEZETÉS - INTRODUCTION}

Jelen cikk központi témája a magyar és az amerikai lakosság internetes vásárlása során vizsgálható fogyasztói magatartás jellemzése. Témaválasztásomat nagyban meghatározta az a kutatói ösztöndíj, amely a Murray State University és a Szent István Egyetem között jött létre, s lehetővé tette, hogy munkám a tengerentúlon végezhessem.
KEYWORDS: e-marketing, consumer behaviour, differences between countries 
a kényelem, a gyorsaság és az otthonról lefolytatható, akár VR szemüvegen keresztül történő élelmiszervásárlás lehetősége.

A témakör megismerése érdekében cikkemet egy rövid szakirodalmi feldolgozással folytatom.

Összefoglalva tehát: elsődleges célkitűzés, hogy az online fogyasztással kapcsolatos kockázatok csökkentésére irányuló magatartási formák mögött húzódó tényezőket feltérképezzem a mintában részt vevők válaszai alapján.

\section{SZAKIRODALMI ÁTTEKINTÉS -} Literature REviEW

A virtuális világban érdekes párhuzamot fedezhetünk fel már a 2000-es évektől, az első magyar, valamint a már bevált, amerikai weboldalak vizsgálata során. Például az amerikai The New York Times, The Wall Street Journal mellett párhuzamosan megjelentek Magyarországon a Figyelő, HVG, FrissHírek online platformjai. A látogató már ekkor, a 2000-es évek elején testre tudta szabni, hogy milyen tartalommal szeretne találkozni a weblap böngészése során (ESZES és BÁNYAI, 2002).

A virtuális platformok látogatóinak túlnyomó többsége idővel végül rendszeres internethasználóvá vált. A világviszonylatban összehasonlított internethasználat penetrációjáról számos publikációt olvashatunk, melyek közül a MINIWATTS (2018) állított össze, majd publikált egy tanulmányt az internetworldstats.com oldalon (adott földrész népessége és internetfelhasználóinak száma, valamint ennek a Föld népességéhez és internetfelhasználóihoz mért százalékos aránya alapján). E kutatás világviszonylatban mintegy 1 066\%os átlagos növekedési trended mutat az internetet használók arányát tekintve (2000-2018). Az internetfelhasználók arányának növekedése elsősorban Afrikában (10,19\%), valamint a Közel-Keleten (4,89\%) volt kiemelkedő. Mivel ezen földrajzi elemzés nem tartalmazza külön Magyarország penetrációját, ezért a fenti elemzést összevetettem a KSH által publikált (2018) adatokkal. A két kutatás külön földrajzi (kontinens és ország) felosztással dolgozott, ezért csupán hozzávetőleges összehasonlításként szolgál.
A KSH (2018) EU-28 (83\%), valamint a MINIWATTS (2018) összesített európai $(85,2 \%)$ adatait tekintve (számottevő eltérést nem tapasztalva) hazánk eredményeit is szemléltetem. Magyarország (76\%), valamint a világ (átlaga 55,1\%) földrészeinek internetpenetrációját az 1. ábra szemlélteti.

Az internetet használók közül nem mindenki vásárol online, így lényeges szempont a virtuális piactéren vásárlók létszáma is. Az amerikai online vásárlók száma 197,6 millió fő volt (MINIWATTS, 2018). Magyarországon ez az érték jóval alacsonyabb, csak 2017-ben haladta meg a 3 millió fót (ORIGO, 2018). Az európai uniós átlaghoz (65\%) képest is alacsonyabb a hazai (47\%) internetfelhasználókból kikerülő online vásárlók száma (PORTFOLIO, 2016).

Online kereskedelmi szempontból a kiskereskedelem forgalma (valamint szereplöinek száma) jelentős mértékben megnövekedett a 2015-ös évben. Az online vásárlások a teljes magyar kiskereskedelmi forgalom 2,5\%-ából részesedtek, 229 milliárd forint volt az árbevételük, 2010 óta pedig évente átlagosan 38\%-kal nőtt az egy évvel korábbi volumenhez viszonyítva (NAGY, 2016).

KNOKE és KOVÁCS (2018) említi, hogy az internet megszüntethet és létrehozhat új üzleti modelleket, hiszen új (kis)kereskedőknek nyit kapukat a potenciális piaci rések irányába, azonban a nagyvállalatokat a hálózati és küszöbhatások sokaságával jutalmazza, amely több esetben monopóliumok kialakulásához vezethet. Az innovatív megoldások, új fejlődési tendenciák, tehát mikro- és makrogazdasági szinten is kiemelt jelentőséggel bírnak. Az IVSZ (2017) kutatása szerint az Ipar 4.0 megjelenésével a digitalizáció világában egyre növekvő értékű állami támogatások kapnak kiemelt figyelmet. Az ehhez kapcsolható szoftverek és applikációk fejlesztésére a korábbiakhoz képest lehetôséget és pénzügyi forrást biztosítottak 2018-ban. Jelen kutatásban a VR szemüvegek otthoni használatát is vizsgáltam a mintán. $\mathrm{Az}$ erre vonatkozó állítás egy élelmiszerbolti vásárlás (szimuláció) lehetőségét veti fel. Az is kiderült, hogy milyen új szükségleteket kell majd kielégíteni a jövőben.

A digitális térben a fogyasztóközpontú gondolkodásmód érvényesül, a személyre szabhatóság termék-, szolgáltatás- és reklámszinten 


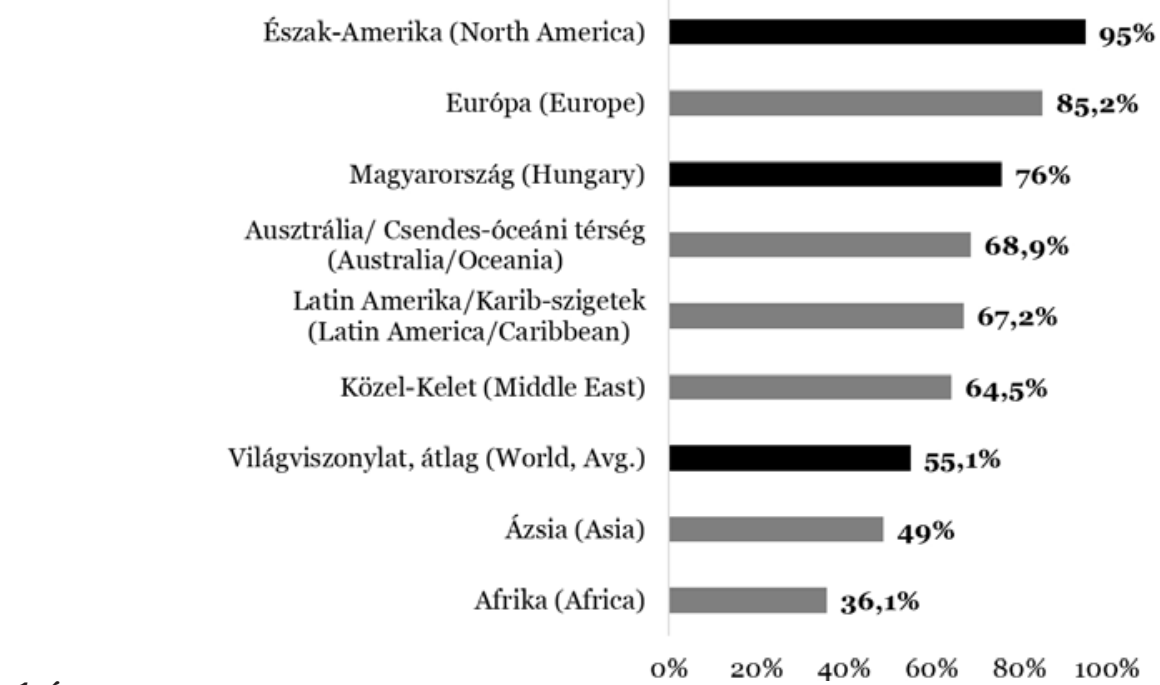

1. ÁBRA

Internet penetráció, 2018

FIG. 1 (Internet World Penetration Rates, 2018)

Forrás (Source): MINIWATTS, 2018 és KSH (2018) alapján saját szerkesztés (Own compilation based on MINIWATTS, 2018 and $\mathrm{KSH}$ (2O18))

is megjelent. ESZES és BÁNYAI (2002) szerint a fogyasztók nem csupán olyan szolgáltatásokat kérhetnek, amiket más weboldalon láttak, hanem olyanokat is, amilyeneket elképzeltek. A fogyasztó saját igényei, elképzelései szerint maga fejleszti és formálja a terméket és/ vagy szolgáltatást. Tehát a marketingfunkciók fejlesztése részben vagy egészben a fogyasztó kezébe kerül. Eközben az Amazon már úgy optimalizálja eladásait, hogy az rugalmasan, gyorsan és racionálisan szolgálja ki a folyamatosan változó vevők szükségleteit, elvárásait, méghozzá 1-1 üzletében akár eladói személyzet alkalmazása nélkül, gépek segítségével, automatizáltan (KNOKE és KOVÁCS, 2018). Hazai szinten legtöbbször azonban egyelőre ezek a megoldások még csupán kiegészítik vagy helyettesítik a hagyományos vásárlási folyamatot (KNOKE és KOVÁCS, 2018; BÁNYAI és NOVÁK, 2011; FEHÉR et al., 2014).

Az online vásárlási döntés tekintetében meg kell említeni a Technológiai Elfogadás Modellt (TAM: Technology Acceptance Model), amely a technológiai fogékonyság és a pozitív fogyasztói attitűd, valamint pozitív bizalom kialakításának lehetőségeire mutat rá (DAVIS et al., 1989, FEHÉR és SZAKÁLY, 2015). SAM és CHAT-
WIN (2015) az online fogyasztói magatartás jellemzőit $\neg$ az eredeti, SPROLES és KENDALL (1986) készített CSI (Customer Style Inventory) leltár alapján az Online Fogyasztói Stílus Leltárban (O-CSI: Online Customer Style Inventory) foglalta össze először. Az eredeti 8 faktorból 7 olyat azonosítottak, amelyek online piactéren is megtalálhatók. Ezek az online fogyasztók magas minőségre törekvése, a márkahűség, a divat, az árérzékenység, a termékek hordozhatósága, a honlap tartalma, valamint a weboldal dizájnja (SAM és CHATWIN, 2015; FEHÉR, 2017).

A fogyasztói magatartást befolyásoló tényezők után kutatva számos meghatározással találkozhatunk. Mikroökonómiai szinten a fogyasztókra az országon belüli gazdasági, politikai, jogi, technológiai, infrastrukturális és kulturális feltételek a jellemzők (REKETTYE et al., 2015). Ezen túlmenően az egyéni preferenciák, személyiségjegyek és körülmények összefüggő tényrendszere befolyásolja a fogyasztót. HOFMEISTER-TÓTH (2014) hozzáteszi, hogy a magyar háztartások fogyasztási mintáit több tényező is befolyásolja. Ezek közül a társadalmi rétegződéssel, az iskolai végzettséggel, a jövedelemmel és a nemek közötti különbségekkel 
foglalkozom jelen kutatásom során.

SÁNDOR (2000) szerint a fogyasztók gyártói ösztönzésének fő tényezője a kipróbálás, a használat során a márkanév megismertetése. A márka- és cégnév népszerüsítése, valamint az eladásösztönzés mára két, jól elkülönítendő marketingcélként jelenik meg, melynek eszköze lehet bármilyen online platform és közösségi csatorna. A fogyasztóra ható tényezők között említhető még a reklám, amelynek tervezése során a látványosság, a humor, a helyhezkötés, az érzékszervi hivatkozás is kiemelt szerepet játszik (MÓRICZ és TÉGLÁSSY, 2004). A fogyasztókra ható látványcentrikusság miatt az okostelefonokkal használható VR szemüvegek vizsgálatát is indokoltnak láttam kutatásom során.

\section{ANYAg ÉS MÓdSZER - MATERIALS AND METHODS}

A tanulmány alapját egy online kérdőív öszszeállítása, majd annak lekérdezése képezte. A standardizált kérdőívet a Szent István Egyetem és a Murray State University, Kentucky hallgatói, illetve az ő ismerősi körükbe tartozók töltötték ki. A lekérdezést a Survey Monkey oldal segítségével végeztem. A magyarországi lekérdezés 2016.09.23. és 2017.01.07. között, az amerikai pedig 2017.02.24. és 2017.05.01. között történt. A kutatás során nyert adatok feldolgozására az IBM SPSS Statistics 21 statisztikai programcsomagot használtam.

Az elemzés az online fogyasztói szokásokkal kapcsolatos kockázatok csökkentésére ható magatartási formákra vonatkozik.

A célcsoport fogyasztói magatartásának pontosabb feltárása érdekében kvantitatív kutatási technikákat vettem igénybe. Az alapkutatás során egy 932 fós mintán hajtottam végre nem reprezentatív felmérést. Ebből a magyarok 729 fót, az amerikaiak 203 főt képviseltek, és kizárásra kerültek az extrém (irreális, mint például egy esetben megadott 1999999 forint, avagy 666666 forint) egy főre jutó nettó jövedelemet megadó válaszadók.

Az online kérdőív elsődleges tárgykörei közé az online vásárlási hajlandóság, a bizalom, az online élelmiszervásárlás VR szemüveggel, valamint az otthonról történő meg- rendelés lehetőségei tartoztak. Ennek alapját korábbi, az online vásárlás népszerüségét és bizalomfejlesztési lehetőségeit vizsgáló tanulmányom adta.

A kérdésekre adott válaszokat először leíró statisztikai elemzéseknek (átlag, szórás, valamint gyakoriság) vetettem alá. Az alkalmazott, 1-5-ig terjedő Likert-skála folytonos ordinális skálát alkot. Ennek megfelelően az összefüggések vizsgálatára paraméteres eljárást alkalmaztam. Az elemzések során létrehozott csoportok, továbbá a köztük lévő különbségek, összefüggések vizsgálata többszempontos varianciaanalízissel történt. Szignifikáns eltérést mutatott a magyar és az amerikai minta elemzése során a jövedelem, a lakhely és a legmagasabb iskolai végzettség, ezért a kérdőív állításaira adott válaszok nemzetek közti összehasonlítása során e változók további szempontokként kerültek az elemzésbe. Összefoglalva tehát a többszempontos varianciaanalízis során a függő változó az egyes, online vásárlásra vonatkozó állításokra (12 db) adott válaszok értékei, míg a független változók a nemzetiség, a jövedelem, a lakhely és a legmagasabb iskolai végzettség lettek.

\subsection{Az elemzés korlátai - Limitations of the Analysis}

A kutatás során nem szabad figyelmen kívül hagyni azt a tényt, hogy a mintavételezés nem reprezentatív, valamint azt sem, hogy a magyar és az amerikai egyetemisták között számtalan különbség tárható fel. Többek között a kulturális és a technológiai differenciák alapvető eltéréseket mutathatnak. Mindezek figyelembevételével olyan elemzéseket fogok végezni, amelyek ezen hasonlóságokra és különbségekre rávilágítanak, majd később további kutatások alapjául szolgálhatnak.

\section{EREDMÉNYEK - REsults}

A kutatás eredményei egy időszerü állapotot mutatnak a 2017. év magyar és amerikai online vásárlókra vonatkoztatva. Az elemzés a minta demográfiai jellemzésével kezdődik. A demográfiai elemzés során a korcsoportok, a nem és a jövedelem közti kiemelt statisztikai összefüggést kaptam, amely jelen tanulmányban is 
helyet kap. Ezt követően az élelmiszervásárlás jelentőségét vizsgáltam meg az online kereskedelem (piactér) tekintetében. Mindemellett figyelemre méltó terület nemzetenként feltérképezni az online vásárolt termékek és szolgáltatások köreit. Az elemzés túlnyomó részét a kérdésekre adott állítások többszempontos varianciaanalízise adja. Ezen állítások során a megkérdezettek preferenciáit vizsgáltam az online vásárlás tekintetében.

\subsection{A minta jellemzése - Characteristics of the Sample}

A felmérésben összesen $\mathrm{N}=932$ fö vett részt. A megadott válaszok alapján ebből 371 férfi (40,1\%) és 555 nő $(59,9 \%)$. Miután a mintát nemzetiségenként különbontottam, az életkor eloszlását vizsgálva, szakmailag indokoltnak tünt négy korcsoport elkülönítése. Ezek a serdülők (16-20 év), a fiatal felnőttek (21-25 év), a pályakezdő felnőttek (26-30 év) és az érett felnőttek (30 év felettiek) elnevezést kapták. A legidősebb válaszadó 73, míg a legfiatalabb 16 éves volt. Az átlagéletkor kerekítve 27 év. A magyar és az amerikai válaszadók életkor-eloszlása hasonlóképp alakult. Eszerint a 21 és 25 , valamint a 26 és 30 év közöttiek vettek részt legtöbben a kutatásban (mindkét nemzetnél hasonló eloszlást követve).

Összességében elmondható, hogy a mintavételben részt vevő válaszadók közül a magyar fogyasztók alacsonyabb jövedelemmel rendelkeznek, mint amerikai társaik $\left(\mathrm{Chi}^{2}{ }^{2}\right)=77391$, $\mathrm{p}<0,001)$. A magyarok jelentősen nagyobb ará- nya rendelkezik jóval az átlag alatti jövedelemmel. A magyar nők 24\%-a, a férfiak 18,4\%-a, az amerikai nők 4,3\%-a, míg az amerikai férfiak közül senki sem tartozott ebbe a jövedelemkategóriába. Az amerikaiak jelentősen nagyobb aránya tartozott átlagos vagy átlag feletti jövedelem kategóriáiba.

$\mathrm{Az}$ amerikai válaszadók közül legtöbben (76,3\%) falun laknak, 14,5\%-uk fóvárosban, illetve 9,1\%-uk városban él. A magyar megkérdezettek közel fele (47,4\%) a fövárosban él, míg 40,5\%-uk városban és mindössze 12\%-uk lakik faluban.

\subsection{Az online élelmiszervásárlás lehetőségeinek vizsgálata - Opportunities of Online Grocery Shopping}

Az elmúlt három hónapban a megkérdezett amerikai fogyasztók döntő többsége vásárolt online (75,5\%, 154 fó), míg a magyarok körében ennek aránya 12,1\% (86 fó) volt. A magyarok nagyobb részére volt jellemző, hogy több éve vásárolt először online (1,5-2 éve; $16,3 \%, 3-4$ éve; 26\%, 5-6 éve; 16,9\%). A válaszadó magyar fogyasztók tehát igen ritkán vásárolnak online.

A magyarok közel 1/4-e (166 fó, 23,3\%) melegételt, élelmiszert, napi fogyasztási cikkeket, valamint több mint 1/5-ük (153 fö, 21,5\%) banki, illetve biztosítási szolgáltatásokat vásárolt online. Az amerikaiak legnagyobb arányban (85 fö, 43,8\%) divatipari termékeket vásárolt az interneten. A kutatás során kapott értékeket az 1. táblázat mutatja be. 
Leggyakrabban vásárolt termékkategóriák a magyar és az amerikai online piactéren (Most Frequently Purchased Product Categories on Hungarian and American Online Market)

\begin{tabular}{|c|c|c|c|c|}
\hline \multirow{2}{*}{$\begin{array}{c}\text { Leggyakrabban vásárolt online termék és } \\
\text { szolgáltatáskategóriák } \\
\text { (Most frequently purchased product and service } \\
\text { categories) }\end{array}$} & \multicolumn{2}{|c|}{$\begin{array}{l}\text { Magyar fogyasztók } \\
\text { (Hungarian } \\
\text { customers) }\end{array}$} & \multicolumn{2}{|c|}{$\begin{array}{l}\text { Amerikai fogyasztók } \\
\text { (American } \\
\text { customers) }\end{array}$} \\
\hline & $\begin{array}{c}\text { Fó } \\
\text { (Person) }\end{array}$ & $\%$ & $\begin{array}{c}\text { Fó } \\
\text { (Person) }\end{array}$ & $\%$ \\
\hline $\begin{array}{l}\text { Divatipari termékek (ruha, cipő, ékszer, kiegészítők stb.) (Fashion } \\
\text { products, for example clothes, shoes, jewelry, accessories, etc.) }\end{array}$ & 110 & 15,5 & 85 & 43,8 \\
\hline $\begin{array}{l}\text { Ételrendelés, élelmiszer, bevásárlás, napi fogyasztási cikkek } \\
\text { (Ordering food, groceries, shopping, daily consumer goods) }\end{array}$ & 166 & 23,3 & 28 & 14,4 \\
\hline Banki és biztosítási szolgáltatások (Bank and insurance services) & 153 & 21,5 & 17 & 8,8 \\
\hline $\begin{array}{l}\text { Jegyrendelés (repülő, koncert, színház stb.) } \\
\text { (Ordering tickets (flight, concert, theatre tickets)) }\end{array}$ & 127 & 17,9 & 10 & 5,2 \\
\hline $\begin{array}{l}\text { Szoftver-, hang- és képanyag-rendelés } \\
\text { (Ordering software, sound or video files) }\end{array}$ & 44 & 6,2 & 21 & 10,8 \\
\hline $\begin{array}{l}\text { Könyvrendelés (Amazon, Bookline stb.) } \\
\text { (Ordering books - Amazon, Bookline, etc.) }\end{array}$ & 47 & 6,6 & 19 & 9,8 \\
\hline $\begin{array}{l}\text { Müszaki, elektronikai termékek (például: telefon, tv, fényképezőgép } \\
\text { stb.) (Electronics (for example: cell phone, tv, smart tv, camera, } \\
\text { etc.)) }\end{array}$ & 64 & 9,0 & 14 & 7,2 \\
\hline
\end{tabular}

Forrás (Source): Saját szerkesztés (Own compilation) 2018

\subsection{Többszempontos varianciaanalízis - Factorial ANOVA}

$\mathrm{Az}$ online fogyasztók preferenciái kérdéskör vizsgálatára a 12 állítást, azaz ,item”-et elemeztem. Erre a 12 állításra 1-től 5-ig tartó Likert-skálán adhattak választ a megkérdezettek, preferenciaszintjüktől függően (1 - Egyáltalán nem értek egyet az állítással, 5 - Teljes mértékben egyetértek az állítással). Plusz változóként jelölhető volt a „Nem válaszol/Nem tudja” lehetőség, amely az elemzése során minden esetben kizárásra került. Külön vizsgáltam a két nemzetiséget, amelyek leíró statisztikai mutatóit a 2. táblázat szemlélteti.

A magyar és az amerikai fogyasztóknál a legnagyobb átlagértéket egyaránt a nagyobb választék és az idő rugalmassága mutatta, míg a harmadik helyen a kényelem állt.
Az átlagok mellett az 1-5-ig skála egyes kategóriának gyakorisági adatai is mutatják a fent leírtakat. A magyaroknál 79,3\% adott 4-es és 5-ös értékelést, az amerikaiaknál 84,7\%.

Mivel a magyar és az amerikai minta szignifikáns eltérést mutatott a jövedelem, a lakhely és a legmagasabb iskolai végzettség esetében, ezért a 12 állítás nemzetek közti öszszehasonlítás során e változók további szempontokként kerültek be az elemzésbe. Így a nemzetiség főhatását, valamint az alábbi, módszertannál már érintőlegesen említett interakciókat vizsgáltam:
1.) nemzetiség,
2.) nemzetiség $x$ lakhely,
3.) nemzetiség $x$ iskolai végzettség,
4.) nemzetiség $x$ jövedelem. 
Alapstatisztikai mutatószámok a magyar és az amerikai online fogyasztói szokások tekintetében (Basic Statistics of Hungarian and American Online Customer Behaviour)

\begin{tabular}{|c|c|c|c|c|}
\hline \multirow{2}{*}{$\begin{array}{l}\text { Online vásárlás indoklása } \\
\text { (J ustification of online shopping) }\end{array}$} & \multicolumn{2}{|c|}{$\begin{array}{l}\text { Magyar fogyasztók } \\
\text { (Hungarian } \\
\text { customers) }\end{array}$} & \multicolumn{2}{|c|}{$\begin{array}{l}\text { Amerikai fogyasztók* } \\
\text { (American } \\
\text { customers) }\end{array}$} \\
\hline & $\begin{array}{l}\text { Átlag } \\
\text { (Mean) }\end{array}$ & $\begin{array}{c}\text { Szórás } \\
\text { (Standard } \\
\text { Deviation) }\end{array}$ & $\begin{array}{l}\text { Átlag } \\
\text { (Mean) }\end{array}$ & $\begin{array}{l}\text { Szórás } \\
\text { (Standard } \\
\text { Deviation) }\end{array}$ \\
\hline Online nagyobb a választék (Selection is bigger online) & 4,01 & 1,21 & 4,22 & 0,81 \\
\hline $\begin{array}{l}\text { Rugalmas idóbeosztás miatt választom } \\
\text { (I choose it because of a flexible schedule) }\end{array}$ & 4,17 & 1,12 & 4,16 & 0,81 \\
\hline $\begin{array}{l}\text { Kényelem miatt választom } \\
\text { (I shop online because it is comfortable) }\end{array}$ & 2,58 & 1,14 & 4,07 & 0,86 \\
\hline Biztonságos az online vásárlás (Shopping online is safe) & 3,67 & 1,33 & 3,79 & 0,85 \\
\hline Online olcsóbb vásárolni (Shopping online is cheaper) & 3,65 & 1,07 & 3,78 & 0,78 \\
\hline $\begin{array}{l}\text { Szeretem megfogni, megérinteni a boltban, látni a saját } \\
\text { szememmel } \\
\text { (I need to touch, see and feel the products at the store) }\end{array}$ & 3,65 & 1,25 & 3,68 & 0,88 \\
\hline $\begin{array}{l}\text { Csak online tudom megvásárolni az adott terméket (I can only } \\
\text { purchase these products online) }\end{array}$ & 2,63 & 1,16 & 3,16 & 0,91 \\
\hline $\begin{array}{l}\text { Interneten csak összehasonlítom a termékeket (I just compare } \\
\text { the products online with each other) }\end{array}$ & 2,69 & 1,25 & 3,16 & 1,01 \\
\hline $\begin{array}{l}\text { Nem biztos a kézbesítés, ha online rendelek (I prefer not to buy } \\
\text { anything online because it is not sure that I will get it) }\end{array}$ & 2,70 & 1,32 & 2,91 & 1,09 \\
\hline $\begin{array}{l}\text { Ha otthonról tudnék egy VR szemüveg segítségével élelmiszer- } \\
\text { boltban vásárolni, akkor mindenképp az online vásárlás mellett } \\
\text { döntenék (If I could shop the groceries online with the help of } \\
\text { VR glasses then I would prefer to shop online in any case) }\end{array}$ & 2,52 & 1,36 & 2,86 & 1,12 \\
\hline Online gyorsabb vásárolni (Shopping online is faster) & 2,80 & 1,30 & 2,82 & 1,02 \\
\hline $\begin{array}{l}\text { Online jobb minőségű terméket kapok } \\
\text { (I get better quality products if I shop online) }\end{array}$ & 3,14 & 1,19 & 2,82 & 0,63 \\
\hline
\end{tabular}

Forrás (Source): Saját szerkesztés (Own compilation) 2018

*Megjegyzés (Note): Az egyes állítások az amerikai válaszadók átlagértékei alapján csökkenő sorrendben lettek feltüntetve (Certain statements have been listed in descending order based on average data of American respondents)

Az elemzés során kapott főhatásokat, elté- megvizsgált 12 állítás esetében (3. táblázat). réseket és interakciókat pontosan jelöltem a 


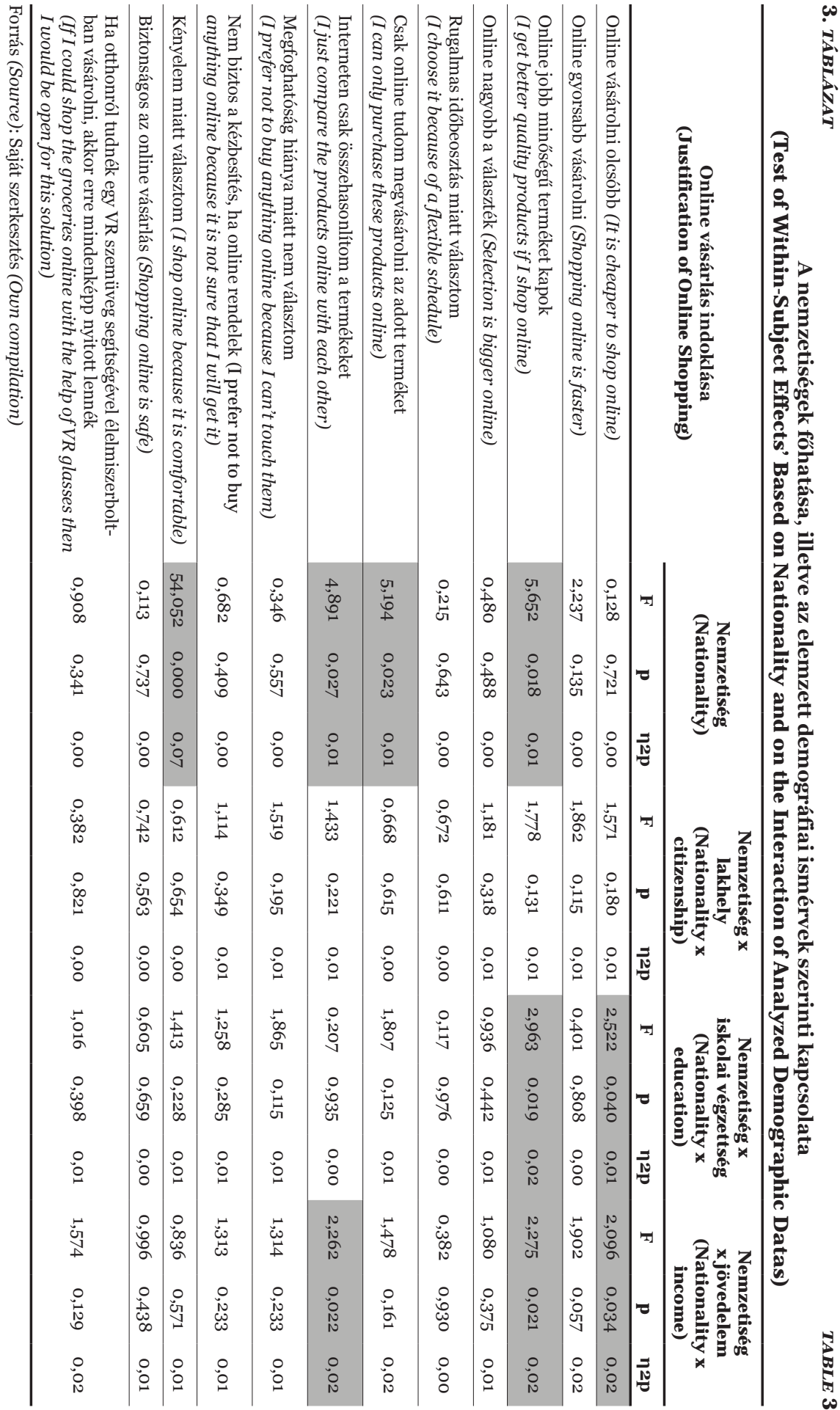


A továbbiakban részletesen bemutatom a szignifikáns fóhatásokat és interakciókat, amelyek a 3. táblázatban szürke színnel lettek megkülönböztetve.

$\mathrm{Az}$ első állításra („Online vásárolni olcsóbb") adott válaszok esetén a nemzetiség x iskolai végzettség $(\mathrm{F}(4,770)=2,522 ; \mathrm{p}=0,040)$ és a nemzetiség x jövedelem $(\mathrm{F}(8,770)=2,096$; $\mathrm{p}=0,034)$ interakciója statisztikailag szignifikáns volt. A nemzetiség x iskolai végzettség interakció esetében az alap- és középfokú végzettséggel rendelkező magyar fogyasztók jobban egyetértettek (átlagérték: $\mathrm{M}_{\text {közép }}=3,77$ ) azzal, hogy az online vásárolt termékek olcsóbbak, mint az ugyanilyen végzettséggel rendelkező amerikai fogyasztók $\left(\mathrm{A}_{\text {közép }}=3,48\right)$. Az ennél magasabb iskolai végzettséggel rendelkező magyar és amerikai fogyasztók véleménye ebben a kérdésben jelentősen nem különbözött (ld. átlagértékek: $\mathrm{A}_{\text {föisk }}=3,60, \mathrm{M}_{\text {föisk }}=3,49$; $\mathrm{A}_{\text {egyetem }}=3,76, \mathrm{M}_{\text {egyetem }}=3,76$ ), amelyet a 2 . ábra mutat be.

4

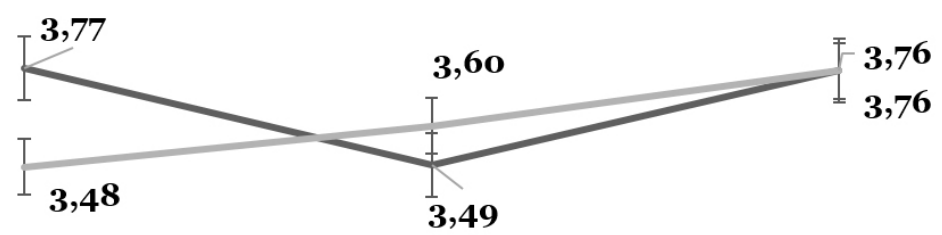

3
Alap- és középfokú képesítéssel
Főiskolai képesítéssel rendelkezók (College qualifications)
Felsőfokú vagy annál magasabb végzettséggel rendelkezők rendelkezók (Primary and
secondary qualifications)
(University or higher education)

\section{2. ÁBRA}

Magyar fogyasztók (Hungarian customers) Amerikai fogyasztók (American customers)

\section{„Online vásárolni olcsóbb” állítás vizsgálata nemzetiség és végzettség szerint, átlagérték (Analysis of the "Shopping Online is Cheaper" Statement Based on Education and Nationaliy, Mean)} Forrás (Source): Saját szerkesztés (Own compilation)

A nemzetiség x jövedelem interakció esetében a magyar fogyasztók inkább egyetértettek azzal, hogy az online vásárolt termék olcsóbb, mint az amerikai fogyasztók. Továbbá a háztartás egy före jutó havi nettó jövedelmét is figyelembe véve (interakció) jelentősen a jóval átlag alatti (átlagértékek: $\mathrm{A}_{\text {jöv.alatt }}=3,04$, $\mathrm{M}_{\text {jöv.alatt }}=3,43$ ), illetve a jóval átlag feletti (nettó) jövedelem kategóriákban (átlagértékek: $\mathrm{A}_{\text {jov }}$ jóval $=3,38, \mathrm{M}_{\text {jöv.jóval }}=3,75$ ) mutatott különbséget az állítással való egyetértés mértéke.

A magyar fogyasztók statisztikailag szignifikáns mértékben inkább egyetértettek azzal, hogy az online vásárolt termék ,jobb minőségü" (átlagérték: 3,14), mint az amerikaiak (átlagérték: 2,82). A nemzetiség x iskolai vég- zettség $(\mathrm{F}(4,767)=2,963 ; \mathrm{p}=0,019)$ és a nemzetiség x jövedelem $(F(8,767)=2,275 ; \mathrm{p}=0,021)$ interakciója statisztikailag szignifikáns volt. A nemzetiség $\mathrm{x}$ iskolai végzettség interakció esetében mindegyik végzettségi szinten a magyar fogyasztók inkább egyetértettek a ,jobb minőség” állítással, azonban az alap- és középfokú, illetve felsőfokú és annál magasabb végzettséggel rendelkező magyar fogyasztók nagyobb eltérést mutattak az amerikai fogyasztókhoz képest. A magyarok inkább úgy vélték, hogy azért vásárolnak az interneten, mert az online vásárolt termékek minőségileg jobbak, mint az ugyanilyen végzettséggel rendelkező amerikai fogyasztók. Ezt a 3. ábra szemlélteti. 
4

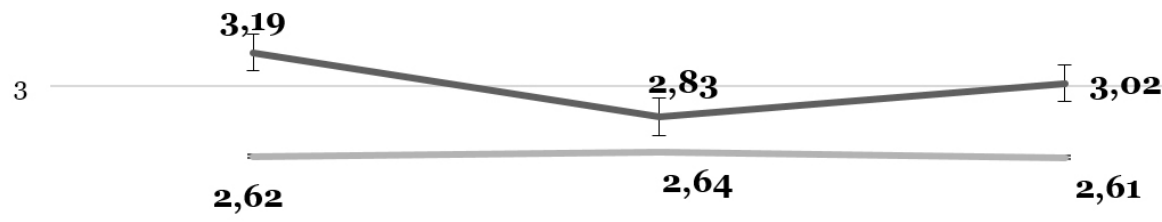

2
Alap- és középfokú képesítéssel Főiskolai képesítéssel rendelkezók rendelkezók (Primary and secondary qualifications)
(College qualifications)
Felsőfokú vagy annál magasabb végzettséggel rendelkezők
(University or higher education)
Magyar fogyasztók (Hungarian customers)
Amerikai fogyasztók (American customers)

3. ÁBRA

„Online jobb minőséget kapok” állítás vizsgálata, átlagérték

FIG. 3

\section{(Analysis of the 'I Get Better Quality If I Shop Online' Statement, Mean)}

Forrás (Source): Saját szerkesztés (Own compilation)

A nemzetiség x jövedelem, tehát a háztartás egy főre jutó havi nettó jövedelmét is figyelembe véve a vizsgálat során az állítással való egyetértés mértéke az összes jövedelemkategóriában különbséget mutatott. Az amerikai e-vásárlók mindegyik jövedelemkategóriában kevésbé értettek egyet azzal, hogy azért vásárolnak online, mert az ott található termékek jobb minőségűek. Jelentősen nagyobb eltérést az átlagos jövedelműek (átlagértékek: $\mathrm{A}_{\text {átlag. }}$ jöv. $=2,87, \mathrm{M}_{\text {átlag.jöv }}=3,27$ ), valamint a jóval átlag feletti (átlagértékek: $A_{\text {jöv.jóval }}=2,51, M_{\text {jöv. }}$ jóval $=3,09)$ jövedelemmel rendelkezők mutattak a két nemzet fogyasztói szokásainak vizsgálata esetében (4. ábra).

4

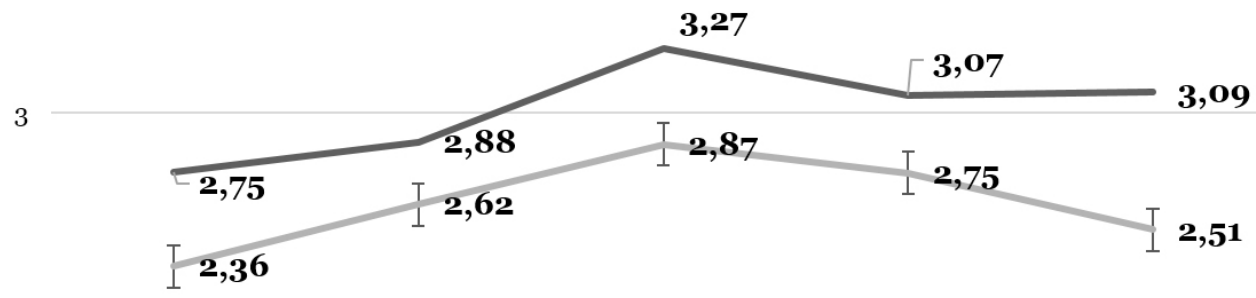

2

\begin{tabular}{|c|c|c|c|c|}
\hline $\begin{array}{l}\text { Jóval az átlag alatti } \\
\text { jövedelem (Income } \\
\text { well below the } \\
\text { average) }\end{array}$ & $\begin{array}{l}\text { Átlag alatti } \\
\text { jövedelem (Income } \\
\text { below the average) }\end{array}$ & $\begin{array}{l}\text { Átlagos jövedelem } \\
\text { (Average income) }\end{array}$ & $\begin{array}{c}\text { Átlag feletti } \\
\text { jövedelem (Income } \\
\text { over the average) }\end{array}$ & $\begin{array}{c}\text { Jóval átlag feletti } \\
\text { jövedelem (Income } \\
\text { well over the } \\
\text { average) }\end{array}$ \\
\hline
\end{tabular}

\section{4. ÁBRA}

Nemzetiség és jövedelem vizsgálata, átlagérték

(Analisys of Nationality and Income, Mean)

FIG. 4

Forrás (Source): Saját szerkesztés (Own compilation) 
A hatodik állításra („Csak online lehet megvásárolni a terméket”) adott válaszok esetén a nemzetiség statisztikailag szignifikáns főhatást mutatott $(\mathrm{F}(1,758)=5,194 ; \mathrm{p}=0,023)$. Az amerikai e-vásárlók szignifikáns mértékben inkább egyetértettek azzal, hogy az online vásárolt termékeket csak az interneten tudják megvásárolni (átlagérték: 3,16), mint a magyarok (átlagérték: 2,63).

A hetedik állításra („Interneten csak összehasonlítok”) adott válaszok esetén a nemzetiség statisztikailag szignifikáns főhatást mutatott $(\mathrm{F}(1,752)=4,891 ; \mathrm{p}=0,027)$. Az amerikai fogyasztók szignifikáns mértékben inkább egyetértettek azzal, hogy online csak összehasonlít- ják a megvásárolni kívánt terméket (átlagérték: 3,16), mint a magyarok (átlagérték: 2,69). A nemzetiség x jövedelem $(\mathrm{F}(8,752)=2,262$; $\mathrm{p}=\mathrm{O}, 022)$ interakciója statisztikailag szignifikáns volt. Az 5. ábra szemlélteti a nemzetiség x jövedelem interakciót, amely esetében csak a jóval átlag alatti jövedelem kategóriájában mutattak az amerikai és a magyar fogyasztók közel azonos értéket. A további jövedelemkategóriákban az amerikaiak inkább értettek egyet azzal, hogy azért böngésznek az interneten, mert ott csak összehasonlítják a termékeket, mint az ugyanilyen jövedelemmel rendelkező magyar fogyasztók.

4

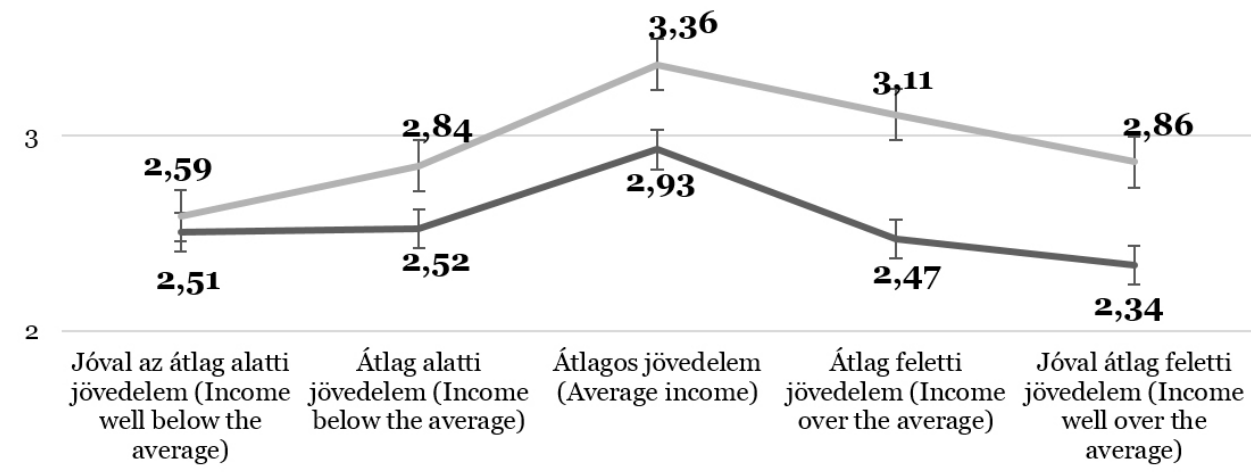

Magyar fogyasztók (Hungarian customers) —Amerikai fogyasztók (American customers)

5. ÁBRA

„Az interneten csak összehasonlítok” állítás vizsgálata, átlagérték ("I J ust Compare the Products Online" Statement's Analisys, Mean)

FIG. 5

Forrás (Source): Saját szerkesztés (Own compilation)

A tizedik állítás („Kényelmesebb az online vásárlás”) elemzése esetén a nemzetiség statisztikailag szignifikáns fóhatást mutatott $(\mathrm{F}(1,767)=54,052 ; \mathrm{p}=0,000)$. Tehát az amerikai fogyasztók szignifikáns mértékben inkább egyetértettek azzal, hogy az online vásárlást a kényelem miatt preferálják (átlagérték: 4,07), mint a magyarok (átlagérték: 2,58).

A további főhatások és interakciók nem mutattak statisztikailag szignifikáns eredményt. 


\section{KonkLÚzió - CONCLUSION}

A témaválasztás időszerü, aktuális. Jelen kutatásban elemzésre kerültek a - nem reprezentatív - minta alapján a magyar és az amerikai online vásárlók nemzetiségbeli és demográfiai azonosságai, valamint különbségei.

A cikk első célkitűzése a kutatási eredmények elemzése során feltárni a nemzetenként eltérő online termék- és szolgáltatáskategóriákat. A kutatásban résztvevő magyar fogyasztók többsége a leggyakrabban vásárolt online termék és/vagy szolgáltatáskategóriák közé a melegételt, az élelmiszert és a napi fogyasztási cikkeket sorolta, valamint $1 / 5$-ük jelölte, hogy igénybe veszi az online biztosítók és bankok oldalait. A megkérdezett amerikaiak leginkább divatipari termékeket, ruhanemúket és kiegészítőket vásárolnak online. További kutatások során kiderült, hogy az eltérő fogyasztói szokások egyik fő oka, hogy a vizsgált régióban szinte egyáltalán nincsen melegétel kiszállítás, csupán a hétköznapi bevásárlás lehetősége adott (például napi fogyasztási cikkek, félkész termékek vásárlása, stb.).

További kutatási cél volt a tanulmány eredményei alapján feltárni, hogy mely változók, illetve milyen információk játszhatnak szerepet az online vásárlás előnyben részesítésében. Ezt az 1. táblázat „online vásárlás indoklásának” állításai tartalmazzák, amelyek összefoglalják az online vásárlás előnyeit és hátrányait. A fogyasztók preferenciáit vizsgálva a nemzetiség tekintetében a „jobb minőség”, a „csak online vásárolható” meg a termék, továbbá a „kényelem”, illetve az „interneten csak összehasonlítom” állításokban volt szignifikáns különbség. Ezen túlmenően a „jobb minőség” esetében a nemzetek között tapasztalt demográfiai különbségek (mint például a személyek iskolai végezettsége és jövedelme) is jelentősen befolyásolták a kapott eredményeket. Példaként említve a ,jóval átlag alatti jövedelem” kategóriájában mutattak az amerikai és a magyar fogyasztók közel azonos értéket. A további jövedelem kategóriákban az amerikaiak inkább értettek egyet azzal, hogy azért böngésznek az interneten, mert ott csak összehasonlítják a termékeket, mint az ugyanakkora jövedelemmel rendelkező magyar fogyasztók. A vizsgálat az „interneten csak összehasonlítom” állítás esetében, jövedelem szintenként mutatott kiemelt eltérést.

$\mathrm{Az}$ online élelmiszervásárlásra kiterjedő kérdésben a VR szemüveg segítségével, otthonról intézhető virtuális élelmiszerbevásárlás lehetőségét vizsgáltam, ahol mindkét nemzetiség esetében közepes, relatív semleges értéket kaptam. Eszerint az élelmiszerboltban tett virtuális bevásárlás lehetőségére nem kaptam egyértelmü, pozitív eredményt.

Mostani kérdőíves megkérdezésem eredményei alapján további potenciális kutatási témakörök merültek fel számos tudományterületre vonatkoztatva (pl. a robottechnika és a szoftverfejlesztés), amelyeket a késóbbiek során további kutatásokkal fogok megvizsgálni.

\section{KöSZÖNETNYILVÁNÍTÁS -}

\section{ACKNOWLEDGEMENT}

„Az Emberi Erőforrások Minisztériuma ÚNKP18-3 kódszámú Új Nemzeti Kiválóság Programjának támogatásával készült”

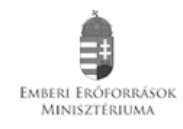

\section{IRODALOMJEGYZÉK - REFERENCES}

Bányai, E. - Novák, P. (szerk.): Online üzlet és marketing. Akadémia Kiadó Kft., 2011.

Davis, F. D. - Bagozzi, R. P. - Warshaw, P. R.: User Acceptance of Computer Technology: A Comparison of Two Theoretical Models. Management Science. 1989. 35 (8) 982-1003. https://doi. org/10.1287/mnsc.35.8.982

Eszes, I. - Bányai, E.: Online marketing. Akadémia Kiadó Zrt., 2002.

Fehér, A. - Soós, M. - Szakály, Z.: $\mathrm{Az}$ élelmiszer-fogyasztói magatartás vizsgálata online környezetben: Létezik-e hazánkban digitális élelmiszerfogyasztó? Táplálkozásmarketing. 2014. 1 (1-2) 2938. https://doi.org/10.20494/TM/1/1-2/3 
Fehér, A. - Szakály, Z.: A hazai lakosság internettel kapcsolatos attitűdjei a TAM modell alapján. Az EMOK XXI. országos konferenciájának tanulmánykötetete. Budapesti Múszaki Egyetem, Budapest, 2015.08.27-28., 388-398.

Fehér, A.: Online élelmiszer-vásárlói és fogyasztói magatartás. In: Élelmiszermarketing (Szerk.: Szakály, Z.) Akadémiai Kiadó, Budapest, 2017. 108-120.

Hofmeister-Tóth, Á.: A fogyasztói magatartás alapjai. Akadémiai Kiadó Zrt., 2014.

IVSZ: Indul a Digitális Jólét Program 2.o., Szövetség a Digitális Gazdaságért, 2017. URL: http://ivsz.hu/hirek/indula-digitalis-jolet-program-2-o/ (Letöltés dátuma: 2018.04.03.)

Knoke, F. - Kovács, S.: A (közel) jövő bevásárlóközpontja. Chip. MediaCity Kft., 2018. 28-30.

Központi Statisztikai Hivatal, KSH: Rendszeres internethasználók aránya Európában (2007-2018) a 16-74 éves személyek százalékában, 2018. URL: https://www.ksh.hu/docs/hun/eurostat_ tablak/tabl/tinooo91.html (Letöltés dátuma: 2018.12.28.)

Miniwatts: World Internet Useage and Population. June 30, 2018. URL: https:// www.internetworldstats.com/stats.htm (Letöltés dátuma: 2018.12.28.)

Móricz, É. - Téglássy, T.: Kreatív tervezés a reklámban. Aula Kiadó Kft., Budapest, 2004.

Nagy, Cs.: KSH: folyamatosan bövül az e-kereskedelem, 2016. URL: http:// eloben.hu/gazdasag/2016-05-01/kshfolyamatosan-bovul-az-e-kereskedelem (Letöltés dátuma: 2018.12.28.)
Origo: Már több mint hárommillió magyar vásárol az interneten, 2018. URL: http:// www.uzletresz.hu/eladas/20180508online-internetes-vasarlasok-szamamagyarorszagon-2018.html (Letöltés dátuma: 2018.12.28.)

Portfolio: Itt az uniós országok digitális rangsora: Magyarország lemaradt, 2016. URL: https://www.portfolio.hu/ vallalatok/it/itt-az-unios-orszagokdigitalis-rangsora-magyarorszaglemaradt.227771.html (Letöltés dátuma: 2018.12.28.)

Rekettye, G. - Tóth, T. - Malota, E.: Nemzetközi marketing. Akadémia Kiadó Kft., Budapest, 2015.

Sam, K. M. - Chatwin, C.: Online Customer Decision-Making Styles for Enhanced Understanding of Macau Online Customer Behavior. Asia Specific Management Review. 2015. 20 (2) 100-107. https:// doi.org/10.1016/j.apmrv.2014.12.005

Sándor, I.: A marketingkommunikáció kézikönyve. Képíró Nyomdaipari, Kereskedelmi és Szolgáltató Kft, Budapest, 2000.

Sproles, G. B. - Kendall, E. L.: A Methology for Profiling Consumers' Decision-making Styles. Journal of Consumer Affairs. 1986. 20 (4) 267-279. https://doi org/10.1111/j.1745-66o6.1986.tboo382.x

\section{JEGYZETEK $*$ NOTES}

